\title{
引張試験法による粉体一絆維系混合物中の 繊維の解縡状態の評価
}

\author{
Apprication of a Tensile Test Method for the Evaluation of \\ Unraveling State of Fibrous Filler in Powder-Fiber Mixtures
}

\author{
須 貝 幸 廉 ${ }^{*}$, 佐 藤 宗 武* \\ Yoshiyuki SUGAI, Munetake SATOH
}

\begin{abstract}
Characterstic curves of tensile stress versus displacement ( $\sigma-\delta$ curve) for loosely packed powder beds (high void fraction) containing fibrous materials have been measured to evaluate the mixing and unraveling states of fibers as a filler for composite materials by using a separable cell type tensile tester. The values of energy consumption calculated from the $\sigma-\delta$ curves were used to discuss the relationships among unraveling and/or formation of the fiber network state in the bulk powders and experimental conditions.

As a result, it has been shown that the unraveled degree of fibers could be evaluated by the calculated energy consumption for pulling out a single fiber from the powder bed.
\end{abstract}

Key Words : Tensile Test, Powder Mixing, Aramid Fiber, Fiber Network, Energy Consumption

\section{1. 緒言}

バルク粉体中に䄉維フィラーを分散充填させた複合 材の強度や摩耗特性などの諸物性は, フィラーの解織 と分散状態に影響されることが知られている ${ }^{1} 。 フ ィ$ ラーの分散状態は多くの場合, 混合物をいったん成形 や固化処理をして適当な形のテストピースにしてか ら，表面や断面などのミクロな観察や，マクロな力学

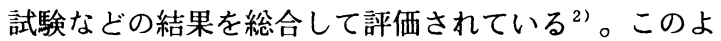
うな成形および固化処理をする前段階の, 混合直後に おける混合物内の緉維解緉状態を評価する試みとし て, 前報 ${ }^{3)}$ では, 混合物を比較的低荷重の条件で圧縮 しながら嵩密度変化を測定し, 混合操作条件との関係 を検討した。

本報では，引き続き炭酸カルシウム/アラミド䄉維 系の試料について, 混合解織処理直後の混合物内のバ ルク粉体層中における緘維の分散と, 擮維同士の網目 形成による複合効果を評価するために引張試験機の利 用を試みた。改良した定容積二分割セル型引張試験機

1998 年 9 月 16 日受付

*大阪府立大学工学部化学工学科

（テ599-8531 大阪府堺市学園町 1-1) TEL 0722-54-9307

Department of Chemical Engineering, Osaka Prefecture University

(1-1 Gakuen-cho, Sakai-shi, Osaka 599-8531)
を用いて，分散された緎維の弾性復元力によって試料 が再膨張しないような低荷重条件で予備成形したスポ ンジ状成形体の引張試験を行い, 引張応力一変位曲線 の特徴と各種実験条件との関係を検討した。

\section{2. 実験装置および方法}

\section{1 引張試験機}

Fig. 1 に使用した引張試験機（Cohetester ; ホソカ ワミクロン社製）の二分割式試料セル部分を示す。セ ルは内径 $50 \mathrm{~mm}$, 高さ $20 \mathrm{~mm}$ の分割円筒で, 一方(1) は本体に固定され，他方(2)は可動台(3)に固定され架台 から吊り下げられている。セルには高さ $10 \mathrm{~mm}$ まで 圧縮した混合物を一定層高のまま引っ張ることが出来 るように，セル上面に半円形状の押さえ板(4)，(5)をそ れぞれ取り付けるようにした。セル底面および押さえ 板の試料接触面には\# 600 のサンドペーパーを貼り 付けて，試験中の試料の滑りを防止した。引張距離は $5 \mathrm{~mm}$ 以上まで可能であり, 可動部全体の変位に対す る求心応力をあらかじめ補正してある。なお, 引張応 力と変位はそれぞれ歪ゲージ式ロードセルと差動卜ラ ンス型変位計により検出され， A/D コンバータを介 してパーソナルコンピュータで連続的に計測される。

\section{2 試料および混合物の調製}

モデル試料物質として, 個数中位径 $D_{50}$ が $2.7 \mu \mathrm{m}$, 


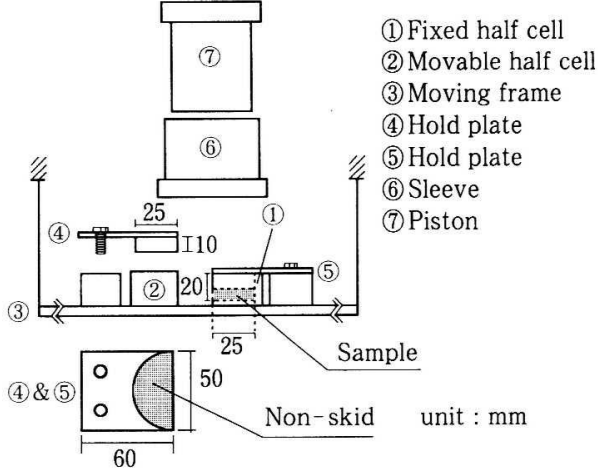

(a) Schematic diagram of apparatus

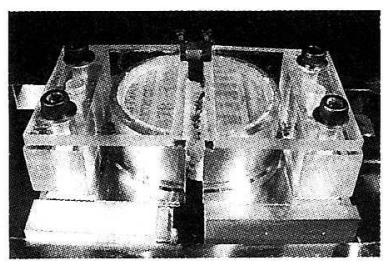

(b) Photograph of test section

Fig. 1 Schematic diagram of apparatus and photograph of test section

真密度 $2600 \mathrm{~kg} / \mathrm{m}^{3}$ の炭酸カルシウム (Super \# 1500 ; 丸尾カルシウム) と, 平均径 $12 \mu \mathrm{m}$, 平均長 さ $1000 \mu \mathrm{m}$, 真密度 $1440 \mathrm{~kg} / \mathrm{m}^{3}$ のアラミド䋐維 （kevler；DuPont）を使用した。

混合物の調製方法は前報 ${ }^{3)}$ と同様なので, ここで は概略を記す。容積 $0.011 \mathrm{~m}^{3}$ の高速摚找型混合機 (High-Speed Mixer ; 深江工業) を用いて, 混合お よび解繊が良好な操作条件 (底部円盤回転速度 : 8回/ s, チョッパー回転速度 : 20 回/s）を設定し, 初めに 䋐維原料のみを投入して 60 秒間擋找し予備解繊し た。その後, 炭酸カルシウムを投入して所定の時間ま で混合操作を行った。混合物は直ちに採取して引張試 験に供した。

\section{3 試験方法}

測定はまず，クランプで固定した分割セル上に同内 径のスリーブ6をを装着し，採取した混合物を精秤した 後, 出来るだけ外力を加えないようにしながら偏りが 生じないように少量ずつ分割投入する。次いで，ピス トン(7)を挿入して脱気しながら静かに压縮して層高が $10 \mathrm{~mm}$ になるようにする。荷重をかけた状態で 10 分 間静置した後, ピストンとスリーブを取り除き, 手早 く押さえ板(4)，(5)を取り付けて試料を固定する。ク ランプを解除して可動セルを一定速度 $\left(1.7 \times 10^{-5}\right.$ $\mathrm{m} / \mathrm{s}$ ) で引っ張り, 引張応力 $\sigma$ 之変位 $\delta$ の関係を測

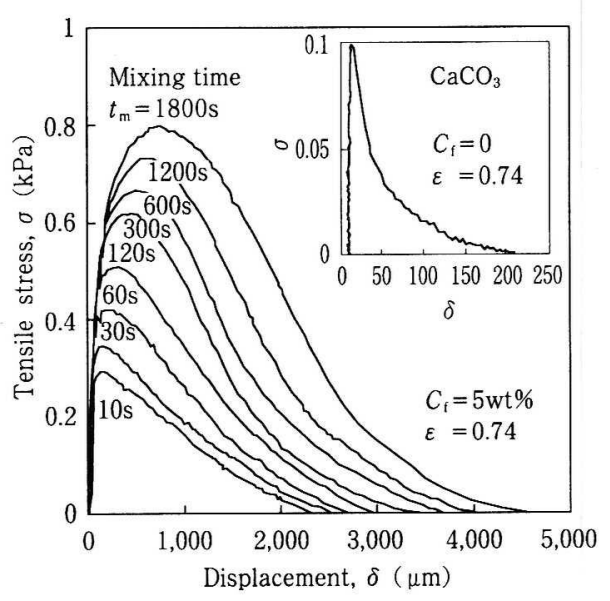

Fig. 2 Typical tensile curves ( $\sigma$ vs. $\delta$ ) for the mixture samples of calcium carbonate powder and aramid fiber (fiber concentration, $C_{\mathrm{f}}=5 \mathrm{wt} \%$, measured at $\varepsilon=0.74$ )

定する。

なお，所定の層高まで試料を圧縮した後の徐荷時 に，スプリングバックによる粉体層内の構造変化また は破壊の進行が出来るだけ少ない条件を選ぶために， 圧縮荷重と混合物の体積変化の関係についてあらかじ め試験を行った。これにはセルと同直径の透明円筒容 器を用いて混合物を載荷荷重を変えて圧縮し, 徐荷時 の層高変化をカセトメータで測定した。瀻維の混合率 によって膨張の仕方は異なったがここでは圧縮方向 への膨張率が全試料層高さ $(10 \mathrm{~mm})$ に対して $1 \sim 2 \%$ 以内の変化に収まる条件を選んで以下の実験を行っ た。

また，測定時のパラメータである試料空隙率 $\varepsilon$ は, セル容積 $\left(19.63 \times 10^{-6} \mathrm{~m}^{3}\right)$ に充媜する試料密度（炭 酸カルシウムとアラミド繊維の混合比により決定）と 質量より算出した。

\section{3. 実験結果および考察}

\section{1 混合試料の引張応力 /変位 $(\boldsymbol{\sigma}-\boldsymbol{\delta})$ 曲線の特 徵}

Fig. 2 に繊維混合率が $5 \mathrm{wt} \%$ の混合試料を，空隙率 $\varepsilon$ が 0.74 の条件でセルに充媜して引張試験を行った 結果の例を示す。炭酸カルシウムのみ（繊維濃度 $C_{\mathrm{f}}=$ Owt\% ）の場合には，右上図に見られるように引張応 力 $\sigma$ は変位 $\delta の$ 增加と共に急激に増大し, ピーク值 $\sigma_{\text {max }}$ に到達後直ちに破断する脆性破壊的な挙動を示 している。これに対して， $5 \mathrm{wt} \%$ の繊維混入試料の 場合には, $\sigma$ は $\delta$ の増加と共に増大し, $\sigma_{\max }$ を示し 


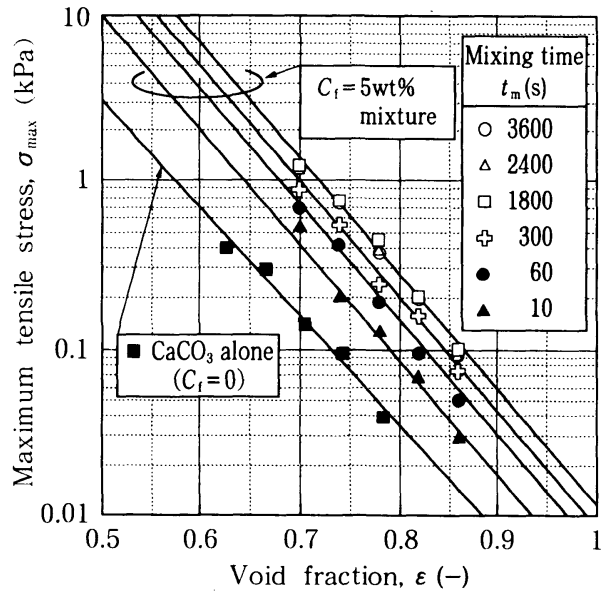

Fig. 3 Relationship between the maximum tensile stress, $\sigma_{\max }$ and the testing void fraction, $\varepsilon$ for $C_{\mathrm{f}}=5 \mathrm{wt} \%$

た後に徐々に低下し破断に至る，一見，塑性変形を伴 う延性破壊的なパターンを示した。このようなピーク から破断に至る曲線は, 測定条件であるセル内の試料 空隙率 $\varepsilon$ にって変化するが, 基本的なパターンは Fig. 2の形を保っている。Fig. 3には $\sigma_{\max }$ の值と $\varepsilon$ の 関係を, 混合時間 $t_{\mathrm{m}}$ をパラメータとして示す。 $\sigma_{\max }$ は $\varepsilon$ の増加と共に減少傾向を示し, 一方, 混合時間を 大きくすると全体的に $\sigma_{\max }$ の值は大きくなり， $t_{\mathrm{m}}=$ $1800 \mathrm{~s}$ 以上では一定の直線に近づいている。この $\sigma_{\max }$ 亡 $\varepsilon$ の関係は, 単一の粉体に対して適用される 次式の指数関数形 ${ }^{4)}$ が本混合物に対しても適用できる ことを示している。

$$
\sigma_{\max }=k \exp (-a \varepsilon)
$$

ここで，混合時間が 1800 秒以上の条件に対して， 式中の係数は $k=9.7 \times 10^{4}, a=15.9$ であった。

$\sigma-\delta$ 曲線は混合時間によって，また後述する紻維 混合率によっても変化しており, 緎維塊の解砕分散過

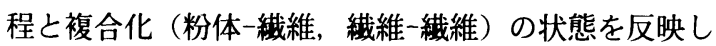
ているものと推察される。

\section{2 引張強度と混合時間の関係}

混合時間を変化させて測定した $\sigma-\delta$ 曲線 (Fig. 2) から, 最大引張応力 $\sigma_{\text {max }}$ とその時の変位 $\delta_{\text {max }}$ を読み とり Fig. 4 に示す。 $\sigma_{\text {max }}$ は混合時間と共に増加して いき, 約 1800 秒で最大となった。さらに混合を続け ると 2400 秒付近まではほぼ一定値を保ったが，それ 以上になると若干低下する傾向を示した。また，試料 が完全に破断する $\delta_{\mathrm{\omega}}$ までの引張距離は $t_{\mathrm{m}}$ と共に増大

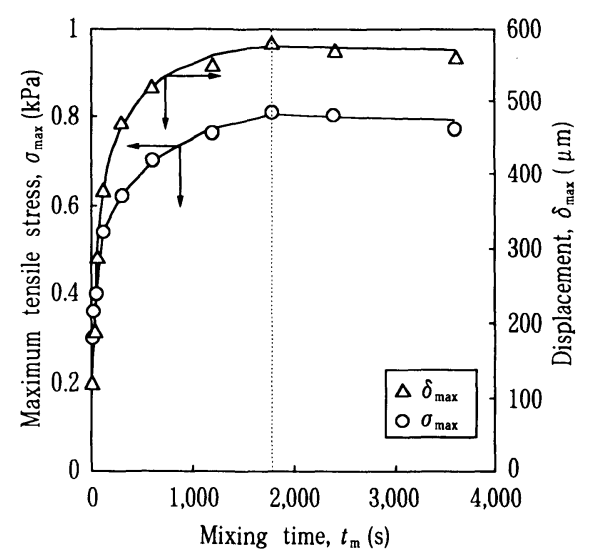

Fig. 4 Variations of the maximum tensile stress, $\sigma_{\text {max }}$ and the displacements, $\delta_{\max }$ at the peak point with the mixing time, $t_{\mathrm{m}}$ (measured at $\varepsilon=0.74, C_{\mathrm{f}}=5 \mathrm{wt} \%$ )

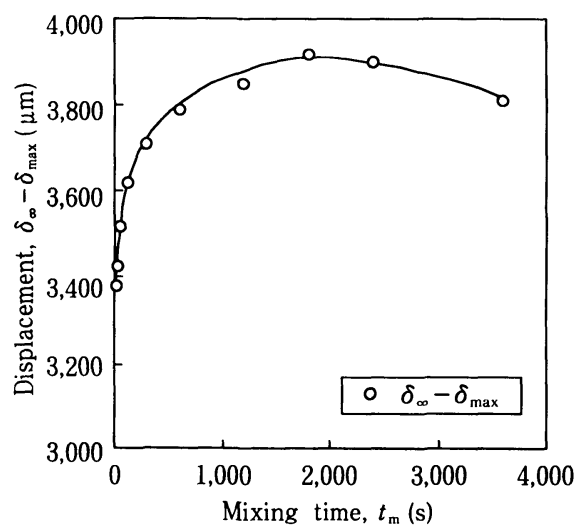

Fig. 5 Relations between the displacement, $\delta_{\infty}-\delta_{\max }$ to the fracture point, $\delta_{\infty}$ from the peak point, $\delta_{\text {max }}$ and mixing, $t_{\mathrm{m}}$

し，1800 秒付近で最大值を示し，その後减少する傾 向を示した。 $\delta_{\max }$ から $\delta_{\infty}$ 迄の伸びを $C_{\mathrm{f}}=5 \mathrm{wt} \%$ につい て Fig. 5 に例示する。

このことは前報3)でも考察したが, 解繊された繊維 の網目に一旦包含された粉体が，擋拌を続けることに よって絞り出されるように分離し, 䄉維のみが毛玉状 の団塊を形成し始める現象に対応している。また， $\delta_{\max } も \sigma_{\max }$ と同様の傾向を示しており, 解緎が進む につれて伸びが大きくなって最大で $580 \mu \mathrm{m}$ (1800秒 混合試料）の值を示している。破断面において平均長 $1000 \mu \mathrm{m}$ の㵶維を粉体層から引き抜くには, 瀻維を 保持する (固定層) 側の粉体層には最低限線維長の半 分以上が埋没している必要があると仮定すると， 580 


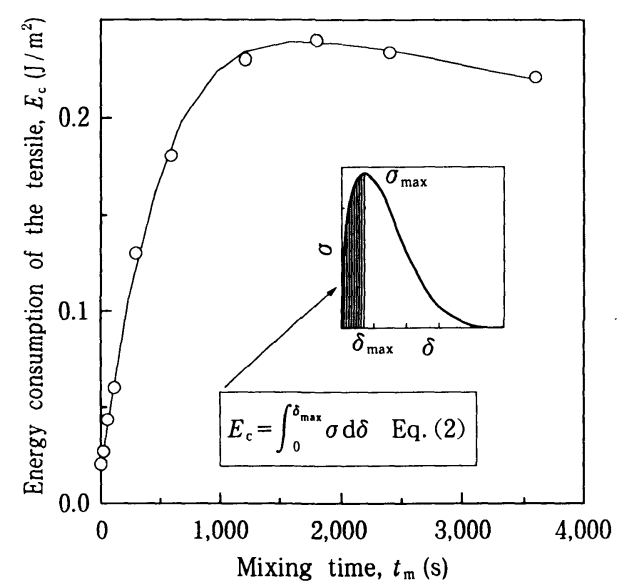

Fig. 6 Effect of the mixing time, $t_{\mathrm{m}}$ on the consumption of the tensile energy, $E_{\mathrm{c}}$ integrating the stress from $\delta=0$ to $\delta_{\max }$ (measured at $C_{\mathrm{f}}=5 \mathrm{wt} \%, \varepsilon=0.74$ )

$\mu \mathrm{m}$ の伸びはこの值を超えている。これは解織の進 行と共に, 綫維同士がある程度相互に重なり合って網 目構造となり, さらに織維のフィブリル（細かい枝分 かれ）が絡み合っているために, 破断面近傍の混合物 が全体的に変形するものと推察される。従って， $\sigma_{\max }$ と $\delta_{\max }$ は䄉維の解絨と網目構造の形成（複合化）状 態を反映する指標の一つと考えられる。そこで, 引張 応力が $\sigma_{\max }$ に至るまでに必要なエネルギー $E_{\mathrm{c}}\left(\mathrm{J} / \mathrm{m}^{2}\right)$ を次式から計算した。ここで， $\delta_{\max }$ は $\sigma_{\max }$ までの距 離である。

$$
E_{\mathrm{c}}=\int_{0}^{\delta_{\max }} \sigma \mathrm{d} \delta
$$

Fig. 6 に $E_{\mathrm{c}}$ と $t_{\mathrm{m}}$ の関係を示す。混合の進行と共に $E_{\mathrm{c}}$ の值が増加し, 1800 秒付近で定常値となり, その後 僅かに減少傾向に転じている一連の解織と複合化プロ セスがこの図で表現されている。

\section{3 引張強度と䋽維濃度の関係}

絨維混合率が 10 数 wt \% を越える高濃度になると, 本擋找装置では各種操作条件を変えても容器内の流動 状態が悪く解䄉が困難になる。一方，1wt \% 以下で は䋐維塊が粉体層中に埋没して流動するため解䋐不良 が起こりやすく, 解䄉されても混合物全体に十分な網 目構造を展開できずに見かけ密度が大きい混合物とな る $^{3)}$ 。

ここでは, 混合試料全体が䄉維の展開によって膨張 するような混合率の範囲内（1～10wt％）で試料を調 製し,引張試験を行った。この䄉維濃度範冊の混合試

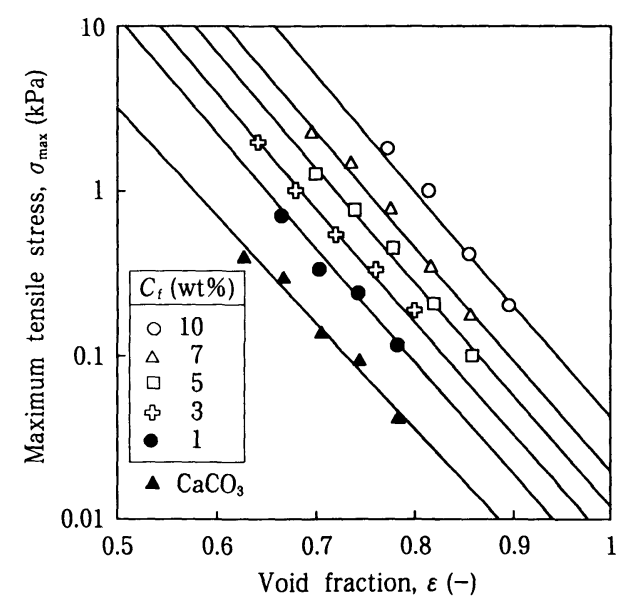

Fig. 7 Effect of the fiber concentration, $C_{\mathrm{f}}$ on the maximum tensile stress, $\sigma_{\max }$ at the steady state of the unraveled degree $\left(t_{\mathrm{m}}=1800 \mathrm{~s}\right)$

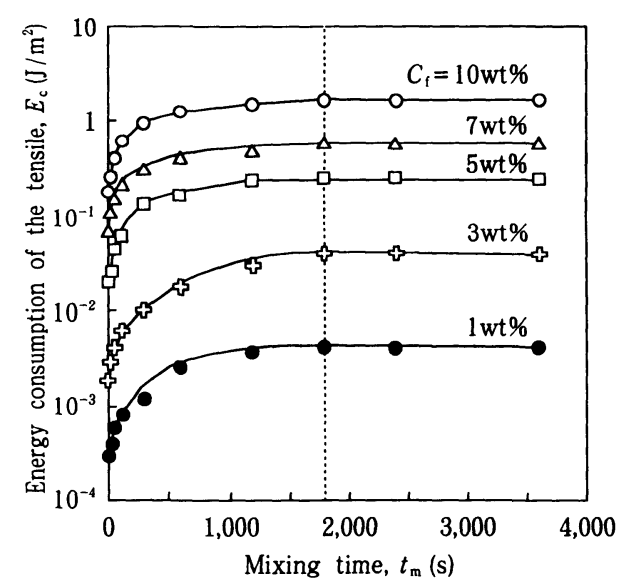

Fig. 8 Relationship between the tensile energy, $E_{\mathrm{c}}$ and mixing time, $t_{\mathrm{m}}$ (measured at $\varepsilon=0.74$ )

料について測定した $\sigma-\delta$ 曲線のパターンはFig. 2 と 同様の傾向を示し，混合時間の增加と共に $\sigma_{\text {max }}$ およ び $\delta_{\text {max }}$ は増大した。また, 瀻維混合率 $C_{\mathrm{f}}$ が增加する と $\sigma, \delta$ 共に大きくなった。

Fig.7には，1800秒間混合した試料についての $\sigma_{\max }$ と $\varepsilon$ の関係を, 㵶維混合率 $C_{\mathrm{f}}$ をパラメータとして示 す。 $\sigma_{\max }$ は $C_{\mathrm{f}}$ の增加と共に増大して行くが, 基本的 にはEq. (1) の形で表現できることが分かる。

$\sigma_{\text {max }}$ に至るまでの変位 $\delta_{\max }$ を用いて $E_{\mathrm{c}}\left(\mathrm{J} / \mathrm{m}^{2}\right)$ を計 算した結果を Fig. 8に示す。図に見られるように䄉維 
Number of fibers exposed on the cross-section, $N_{1}\left(\mathrm{~m}^{-2}\right)$

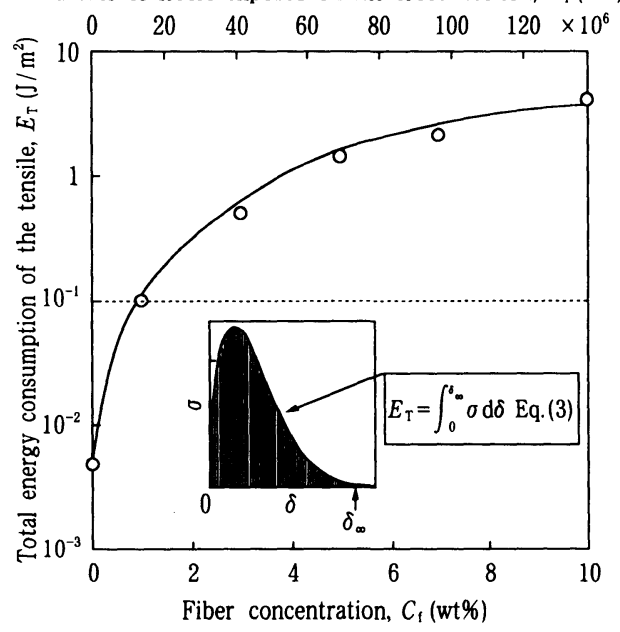

Fig. 9 Compounding effect of the fibers into the powder bed at the steady state $\left(t_{\mathrm{m}}=1800 \mathrm{~s}\right)$ of the unraveled degree (measured at $\varepsilon=0.74$ )

混合率に関わらず, 混合時間が約 1800 秒で $E_{\mathrm{c}}$ は各 $C_{\mathrm{f}}$ の值に応じて一定值に近づき, 前報 ${ }^{3)}$ で示した混合物 の写真観察結果を参照すると, この時点で混合が完了 していると判断できることが分かった。

ここで, 引張試験で得られた $\sigma-\delta$ 曲線 $(0 \leqq \delta \leqq$ $5000 \mu \mathrm{m})$ から単位破断面当たりの全エネルギー $E_{\mathrm{T}}$ $\left(\mathrm{J} / \mathrm{m}^{2}\right)$ を次式Eq. (3) より求めた。

$$
E_{\mathrm{T}}=\int_{0}^{\delta_{\infty}} \sigma \mathrm{d} \delta
$$

$\delta_{\infty}$ は試料が完全に破断した点である。Fig. 9 に $t_{\mathrm{m}}=$ $1800 \mathrm{~s}$ の時点での $E_{\mathrm{T}}$ と䄉維混合率 $C_{\mathrm{f}}$ との関係を示 す。図中には, 後述の Eq. (4) より求められる試料破 断面の単位面積当たりに露出する䋐維数 $N_{\mathrm{f}}$ を $C_{\mathrm{f}}$ 之対 比して記載した。バルク粉体である炭酸カルシウム単 体での $E_{\mathrm{T}}$ は約 $5 \times 10^{-3} \mathrm{~J} / \mathrm{m}^{2}(\varepsilon=0.74)$ であり， $C_{\mathrm{f}}=$ $1 \mathrm{wt} \%$ と比較しても約 $1 / 20$ の值である。従って, 䄉 維が粉体層に展開することによって, 主として引き抜 き時の抵抗として䄉維強化効果が発現しているものと 考えられる。そこで, 簡単な仮定の下で䄉維一本当た りの引き抜きエネルギーの推定を試みた。

\section{4 絨維の引き抜きエネルギー $\boldsymbol{E}_{\mathrm{f}}$ の推定}

混入した緎維が三次元方向に等しい確率で直線状に 等間隔で破断面に直角に配列すると仮定した場合, 単 位面積当たりに露出する㵶維本数 $N_{\mathrm{f}}$ は次のEq. (4)で

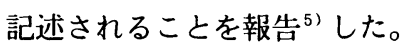

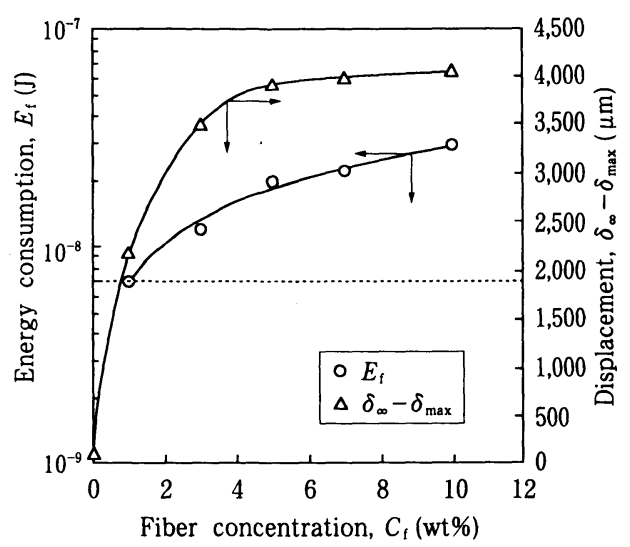

Fig. 10 Energy consumption, $E_{\mathrm{f}}$ for pulling out the single fiber from the powder bed and the displacements, $\delta_{\infty}-\delta_{\max }$ with the fiber concentration, $C_{\mathrm{I}}$ (measured at $\varepsilon=0.74$ )

$$
\begin{aligned}
& N_{\mathrm{f}}=\frac{4 \nu \rho_{0}\left(\sqrt[3]{V_{0}}\right)^{2} C_{\mathrm{f}} \cdot 10^{-2}}{3 \pi d^{2} \rho_{\mathrm{f}}} \\
& \nu=\frac{\rho_{\text {st }}}{\rho_{0}}
\end{aligned}
$$

ここで， $\rho_{0}$ は載荷荷重を変えて測定した試料の嵩密度 值より無荷重時の状態を内挿 ${ }^{3)}$ した值と定義する。

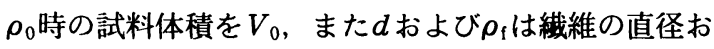
よび真密度である。 ときの圧縮比であり， $\rho_{\mathrm{st}}$ はセル内における試料嵩密 度である。Eqs. (3), (4) より, 䋞維一本当たりの引 き拢きエネルギー $E_{\mathrm{f}}(\mathrm{J})$ を次の Eq. (6) より計算し た。

$$
E_{\mathrm{f}}=\frac{E_{\mathrm{T}}-E_{0} \cdot\left(\frac{A-A_{\mathrm{f}}}{A}\right)}{N_{\mathrm{f}}}
$$

ここで $E_{0}$ は炭酸カルシウム単体の $E_{\mathrm{T}}, A$ および $A_{\mathrm{f}}$ は それぞれ破断面における試料面積および䄉維面積であ る。

Fig. 10に, $t_{\mathrm{m}}=1800 \mathrm{~s}$ における $E_{\mathrm{f}}$ および $\delta_{\max }$ から $\delta_{\infty}$ までの伸びを絾維混合率 $C_{\mathrm{f}}$ との関係として示す。単 純モデルでは $E_{\mathrm{f}}$ は $C_{\mathrm{f}}$ に無関係に一定值をとるはずで

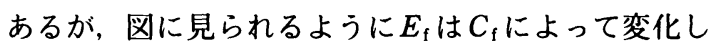
た。これは解緎した紻維のフィブリルが粉体層内で接 触し絡み合っている影響と考えられ, 接触点数が $C_{\mathrm{f}}$ と共に増加していることを示していると推測される。 ただし $C_{\mathrm{f}}$ が $10 \mathrm{wt} \%$ を越えると，図中には示さなか 
ったが，解䋳状態が極端に不良となり，粉体層内に未 解緎の䄉維塊が残存してしまうため $E_{\mathrm{f}}$ は堿少する傾 向を示した。また $\delta_{\max }$ から $\delta_{\infty}$ までの伸びは瀻維が混 入されることにより大きく変化し, 炭酸カルシウムの みと比べて $1 \mathrm{wt} \%$ 混入時でも約 20 倍程度の伸びが認 められた。すなわち $1 \mathrm{wt} \%$ 程度の織維が混入すれ ば，試料混合物中にある程度の䄉維ネットワークが形 成されると考えられる。また $C_{\mathrm{f}}$ が $5 \mathrm{wt} \%$ 程度迄は絨 維濃度の增加と共に $\delta_{\infty}-\delta_{\max }$ は急激に大きくなるが, それ以後変化は小さくなり定常値に近づいている。す なわち， $\delta_{\infty}-\delta_{\max }$ には䋐維濃度が $5 \mathrm{wt} \%$ 以上ではあ まり大きな影響が現れない。これは䋐維ネットワーク の長さが影響していると考えられ, 䄉維の平均長さに 依存すると考えられる。これより, 破断に必要なエネ ルギー $E_{\mathrm{f}}$ は断面に存在する緎維数に依存し，ピーク から破断までの伸び $\delta_{\infty}-\delta_{\max }$ は繊維の平均長さに影響 されると考えられる。

\section{4. 結言}

高速擋拌型混合機を使用して, 混合および解紻され たスポンジ状の炭酸カルシウム/アラミド繊維系試料 について, 解織と試料の混合状態変化を引張試験によ り䄉維濃度が $0 \leqq C_{\mathrm{f}} \leqq 10 \mathrm{wt} \%$ ，混合処理時間が $10 \leqq$ $t_{\mathrm{m}} \leqq 3600 \mathrm{~s}$ の範井において検討し以下の知見を得た。

（1）定容積二分割セル型引張試験機のセルに試料押さ え板を設置することにより，粉体中に䄉維を含んだ スポンジ状試料の $\sigma-\delta$ 曲線が測定可能となった。

（2）引張応力と変位から最大引張応力に至るまでに必 要なエネルギーを求め, これを擋拌時間との関係と して整理することにより, 解緎と複合化プロセスの 一面を評価できた。

（3）試料が完全に破断するまでに必要な緎維一本当た りの引き抜きエネルギーから，粉体首内における䄉 維の枝分かれやフィブリル化ならびに綫維相互間の 接触あるいはネットワーク形成について検討できる 可能性を示した。

\section{Nomenclature}

$A$ : cross-sectional area of sample in testing cell

$\left(\mathrm{m}^{2}\right)$

$A_{1}$ : cross-sectional area of fibers in cross section of sample

$\left(\mathrm{m}^{2}\right)$

$a$ : experimental constant defined by Eq. (1) (-)

$c_{1}$ : fiber concentration

$d$ : average diameter of a fiber

(wt \%)

(m)

$E_{0}$ : energy consumption of the tensile for the calcium carbonate powder

$\left(\mathrm{J} / \mathrm{m}^{2}\right)$

$E_{\mathrm{c}}$ : energy consumption of the tensil

$\left(\mathrm{J} / \mathrm{m}^{2}\right)$

$E_{\mathrm{f}}$ : energy consumption for pulling out the single fiber from the powder bed

$E_{\mathrm{T}}$ : total energy consumption of the tensile $\left(\mathrm{J} / \mathrm{m}^{2}\right)$

$k$ : experimental constant defined by Eq. (1) (-)

$N_{\mathrm{f}}$ : number of fibers exposed on the cross-section $\boldsymbol{t}_{\mathrm{m}} \quad$ : mixing time

$V_{0}$ : volume of sample mixture at $\rho_{0} \quad\left(\mathrm{~m}^{3}\right)$

$\delta \quad$ : displacement

$\delta_{\max }$ : displacement at maximaum tensile stress, $\sigma_{\max }$

$\delta_{\infty}:$ displacement at fracture point

$\varepsilon \quad$ : void fraction

$\nu$ : compression ratio

$\rho_{\mathrm{f}} \quad$ : true density of fiber

$\rho_{\text {st }}$ : bulk density of compressed sample

$\rho_{0}$ : bulk density of unraveled sample

$\sigma \quad:$ tensile stress

$\sigma_{\max }:$ maximum tensile stress (m)

(s)

(m)

(m)

(-)

(-)

$\left(\mathrm{kg} / \mathrm{m}^{3}\right)$

$\left(\mathrm{kg} / \mathrm{m}^{3}\right)$

$\left(\mathrm{kg} / \mathrm{m}^{3}\right)$

$\left(\mathrm{N} / \mathrm{m}^{2}\right)$

$\left(\mathrm{N} / \mathrm{m}^{2}\right)$

$\left(\mathrm{m}^{-2}\right)$

\section{References}

1) Sugai, Y., K. Iida, M. Arai and K. Seki : "Friction Characteristics of Graphite for Brake Friction Materials", J. Soc. Powder Technol., Japan, 33, $782-787$ (1996)

2) Fukuda, H., R. Yokota and I. Shiota : "Fukugouzairyou Kiso Kougaku", pp. 252-263, Nikkan Kougyou (1994)

3) Sugai, Y. and M. Satoh: "The Evaluation of Mixing Process for Dispersing Polymer Fiber Materials into the Powder bed", J. Soc. Powder Technol., Japan, 35, 265-
270 (1998)

4) Tsubaki, J. and G. Jimbo: "Theoretical Analysis of the Tensile Strength of a Powder Bed”, Powder Technology, 37, 219-227 (1984)

5) Sugai, Y., M. Satoh and M. Morita : "Evaluation of Unraveling State of Polymer Fiber Lumps in Powder Matrix using Image Analysis", J. Soc. Powder Technol., Japan, 35, 721-725 (1998) 